воок Visualising Multilingual Lives:

More Than Words

Kalaja, P., \& Melo-Pfeifer, S. (Editors) (2020)

Bristol: Multilingual Matters. 312 pages.

ISBN: 9781788922593

Received: 30/07/2020 | Reviewed: 30/07/2020 | Accepted: 16/08/2020

\section{Martina ZIMMERMANN}

University of Teacher Education, Lucerne martina.zimmermann@phlu.ch
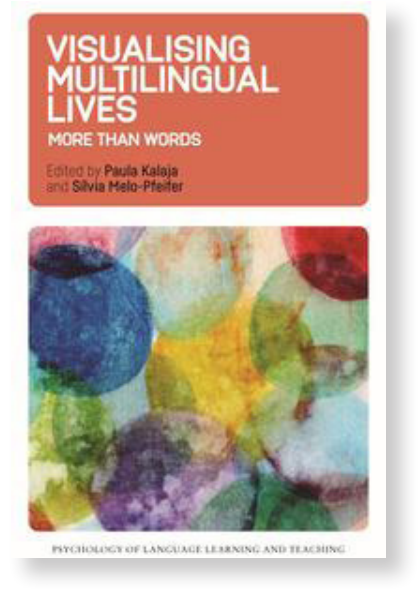

With the aim to improve language learning and teaching and teacher education, linguistic diversity (e.g. in classrooms) has been embraced (rather than erased), which has led to a multilingual turn in applied language studies. The recognition of the "multilingual subject" (Kramsch, 2009) was influenced by the "narrative turn" (Pavlenko, 2007) acknowledging linguistic and discursive productions of individuals. The book entitled "Visualising Multilingual Lives: More Than Words" accentuates the "visual turn" (Kalaja \& Pitkänen-Huhta, 2018), stressing the multisemioticity and its role in individuals' lives. As Busch (2017: 49) puts it, visual narratives and visual methods can be seen as part of the "growing interest in multimodal approaches in applied linguistics, and in biographically oriented research". Including means such as drawings, photographs and computer-generated artefacts, multilingual subjects are visually accessed. In the 13 chapters of "Visualising Multilingual Lives: More Than Words", it is argued that "visual material can present things than words cannot and can therefore be used as evidence and support, or to supplement written research findings" (Rose, 2012: 326). The publication thus demonstrates in what ways visual data is of condensing nature (Weber, 2008) and contributes to reshaping methodological landscapes and empirical research, by approaching new or reshaped realities through new semiotic resources.

The book follows a tripartite structure which is very helpful for readers looking for empirical studies in their area of interest. Each part focuses on one way of discursively and/ or visually constructing identities of the multilingual subjects in a specific context. Part 1, 
entitled "The Multilingual Self”, emphasizes the multilingual users and their languages and insofar sheds light on how they make use of different linguistic repertoires. In Part 2 "The Multilingual Learner", identities are discussed constructed in the process of studying a foreign language. Part 3, "Multilingual Teacher Education", concentrates on teacher education and on multilinguals who are in the process of becoming teachers of English as a foreign or second language.

The authors of the different chapters are very explicit on how and why visual methods add value to their research. Muriel Molinié (chapter 5), for instance, claims that the visual narratives allow the students to adopt a reflexive position in connection with their experience of mobility and become a means to share their identity negotiations. E.g. Mireia Pérez-Peitx, Isabel Civera López and Juli Palou Sangrà (chapter 13) explain that the visual material produced by their participants, who are enrolled in teacher education, helps destabilizing and deconstructing students' representation, which is a necessary step to construct new views. Kristiina Skinnari (chapter 6, p. 113) uses self-portraits to study language learner identity complementing ethnographic data gathered earlier. Referring to Holm (2008), she reminds us that interpretations that "claim to 'reveal' hidden truths" should be avoided by all means and that power relations ("whose story gets told in visual narratives?") do also occur when using visual data. Katja Mäntylä and Paula Kalaja (chapter 14) make use of visual (and verbal) data to investigate future teachers' visions and dreams and thereby take their present and possible or future self into account. This explicitness on how and why visual narratives are applied is a clear strength that should be transferred to future publication projects regardless of working with or without visual methods. It allows the readers to gain a better understanding of why a "lingualist" approach does not suit the chosen research questions. Furthermore, several authors do not shy away from mentioning that a new round of data analysis was necessary and are self-critical of the research design or their own ideological positioning. To openly discuss such a self-critical attitude is still rare, yet it is crucial if we want other researchers to further develop visual methods and to prevent them from "just" adopting it for its potential "trendiness".

Whereas some authors argue that visual data "still need to be contextualized by words, and may remain excessively obscure if they are not" (Rose, 2012: 326) (cf. chapter 11 by Ana Carolina de Laurentiis Brandão), others argue that visual data should not be seen as "subordinate to verbal representations" (Skinnari, p. 97). In the chapter by Sílvia Melo-Pfeifer and Alexandra Fidalgo Schmidt (chapter 4), visual narratives dominate as the reliable collection of verbal data proved difficult with young refugees. A point that could inspire future publications is the discussion of the relationship and the hierarchy between verbal and visual data.

Another aspect that might deserve further scrutiny is how our participants are visu- 
ally socialized. Kristiina Skinnari (chapter 6) pinpoints different stylistic genres (e.g. manga) used by her participants. However, there are several other fascinating sources that we could try to tackle. For example, are there any visual norms that our participants might refer to? What sort of visual images do I, the researcher, have when it comes to language learning and teaching or being multilingual and in what ways are these ideologically loaded? In what ways are these images congruent or not with those our participants align to?

The book is insofar remarkable as it does what the title promises: it really is "more than words". It is one of the rare publications in which pictures/drawings are printed in color and enough space is dedicated to them. However, I could still imagine that the importance attributed to visual data could be taken to yet another level. Is it possible that we, the researchers, could try to go beyond the traditional book project by taking our participants' visual, interactive and communicative reality into consideration? Could we envisage some online publication which forces us to deviate from the "linear" reader experience and, for example, allow the reader to move the cursor to an image/visualization which is accompanied by the researcher's interpretation. This is not to be understood as a critique of "Visualising Multilingual Lives: More Than Words", it is rather an attempt to close the gap between the complexity met when gathering data and the somewhat rigid publication traditions established in academia.

To sum up, "Visualising Multilingual
Lives: More Than Words" does provide a lot of food for thought for researchers, lecturers and linguists whose interest goes beyond language. And if we want to take multilingual lives seriously, it is without question that other semiotic resources cannot be ignored any longer.

\section{References}

Busch, B. (2017). Moving beyond "lingualism": Multilingual embodiment and multimodality in SLA. In S. May (Ed.), The multilingual turn: Implications for SLA, TESOL and bilingual education (pp. 54-77). Oxford: Routledge.

Holm, G. (2008). Visual research methods. Where are we and where are we going? In S. Nagy Hess-Biber \& P. Leavy (Eds.), Handbook of emergent methods. New York: Guilford Press.

Kalaja, P., \& Pitkänen-Huhta, A. (Eds.) (2018). Double special issue "Visual methods in applied language studies". Applied Linguistics Review, 9(2-3), 157-473.

Kramsch, C. (2009). The multilingual subject: What foreign language learners say about their experience and why it matters. Oxford: Oxford University Press.

Pavlenko, A. (2007). Autobiographic narratives as data in applied linguistics. Applied Linguistics, 28, 163-188.

Rose, G. (2012). Visual methodologies: An introduction to researching with visual materials ( $3^{\text {rd }}$ ed). London: Sage. 
DIDACTICAE | Universitat de Barcelona | ISSN 2462-2737 | DOI: 10.1344/did.2020.8.209-212

Weber, S. (2008). Using visual images in research. In J.G. Knowles \& A.L. Cole (Eds.), Handbook of the arts in quali- tative research: Perspectives, methodologies, examples, and issues (pp. 41-53). London: Sage. 